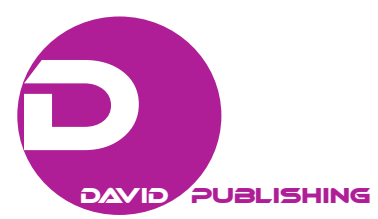

\title{
Existing Contradictions and Recommendations to China's Insurance Industry Characterized by Low-growth and
}

\section{Low-interest}

\author{
Wang Xujin, Guo Xia, Yi Shanmei \\ Insurance Department of Beijing Technology and Business University, Beijing, China
}

\begin{abstract}
This article seeks to analyze the contradictions and recommendations to China's insurance industry in the context of low-growth and low interest market. Under the pressure caused by the contradictions between the sustainable growth in the insurance premium income and the low ROI, it is very important to solve these contradictions for maintaining a sustainable and steady growth in insurance industry, at the same time, it is also favorable to play a role as a social stabilizer as well as an economic booster for insurance industry. This paper can be divided into four parts: Part I analyzes the five basic characteristics of Chinese low-growth and low-interest insurance industry; part II elaborates the principal contradictions faced by Chinese low-growth and low-interest insurance industry; part III analyzes the development environment of Chinese insurance industry; part IV proposes the recommendations to solve these contradictions.
\end{abstract}

Keywords: low-growth, low-interest, insurance industry, market economy, restructuring, capital market

\section{Introduction}

Since Chinese insurance industry restored in 1980, the insurance premium income increased from 460 million yuan in 1980 to 1.433925 trillion yuan in 2011 and the annual growth rate was more than $20 \%$. In 2012, although the number of insurance premium income reached 1.55 trillion yuan, the growth rate was only $8 \%$ and the ROI (rate of return on investment) was only $3.38 \%$. So under the pressure caused by the contradictions between the sustainable growth in the insurance premium income and the low ROI, it is very important to solve these contradictions for maintaining a sustainable and steady growth in insurance industry, at the same time, it is also favorable for insurance to play its role as a social stabilizer as well as an economic booster. This paper

\footnotetext{
Wang Xujin, professor of Insurance, Director of Insurance Department of Beijing Technology and Business University, Director of Insurance Research Center of Beijing Technology and Business University, member of the People's Republic of China Ministry of Education Finance Teaching Guidance Committee, standing executive director of the Asia-Pacific Risk and Insurance Association, executive director of the Insurance Institute of China, Arbitrator of the Beijing Arbitration Commission, Insurance Department of Beijing Technology and Business University, Beijing, 100048 P. R. China.

Guo Xia, graduate student majoring in risk management and insurance, Insurance Department of Beijing Technology and Business University, Beijing, 100048 P. R. China.

Yi Shanmei, graduate student majoring in risk management and insurance, Insurance Department of Beijing Technology and Business University, Beijing, 100048 P. R. China.

Correspondence concerning this article should be addressed to Wang Xujin, Insurance Department of Beijing Technology and Business University, 33 Fucheng Road, Haidian District, Beijing, 100037 P. R. China. Tel: (+) 8613611282321. E-mail: wangxujin@foxmail.com.
} 
seeks to propose the corresponding solutions based on the analysis of the characteristic low growth rate of China's insurance industry and the contradictions and environment it is faced with.

\section{Characteristics of China's Insurance Industry with Low Growth Rate and Low Rate of Return}

Firstly, the growth rate has fallen back to one digit, while property insurance achieved a higher growth rate than personal insurance. From 460 million yuan in 1980 to 1.55 trillion yuan in 2012, China has become one of the leading roles in premium income, with the international ranking rising from 13th (Ulrike Birkmaier, 2002) when joining the World Trade Organization (WTO) in 2001 to sixth (Daniel Staib, 2011) in 2010. While the scale keeps expanding, the growth rate dropped from an average of more than $20 \%$ to only $8 \%$ in 2012 . In comparison with the relatively fast-growing property insurance, the growth rate of personal insurance decreased to one digit of $7.1 \%$ and $4.6 \%$ for the latest two years in the Table 1 respectively.

Table 1

Growth of Premium Income in China From 1980 to 2012

\begin{tabular}{|c|c|c|c|c|c|c|c|c|}
\hline Year & $\begin{array}{l}\text { GDP } \\
\text { (million } \\
\text { yuan) }\end{array}$ & $\begin{array}{l}\text { Growth rate } \\
(\%)\end{array}$ & $\begin{array}{l}\text { Premium } \\
\text { income } \\
\text { (million yuan) }\end{array}$ & $\begin{array}{l}\text { Growth rate } \\
(\%)\end{array}$ & $\begin{array}{l}\text { Property insurance } \\
\text { premium income } \\
\text { (million yuan) }\end{array}$ & $\begin{array}{l}\text { Growth rate } \\
(\%)\end{array}$ & $\begin{array}{l}\text { Life insurance } \\
\text { premium } \\
\text { income } \\
\text { (million yuan) }\end{array}$ & $\begin{array}{l}\text { Growth rate } \\
(\%)\end{array}$ \\
\hline 1980 & 451,780 & 7.8 & 460 & - & 460 & - & - & - \\
\hline 1981 & 486,240 & 5.2 & 780 & 69.5 & 780 & 69.5 & - & - \\
\hline 1982 & 529,470 & 9.1 & 1,030 & 32.1 & $1,028.4$ & 31.8 & 1.6 & - \\
\hline 1991 & $2,161,780$ & 9.2 & 17,824 & 31.9 & 13,683 & 28.17 & 4,141 & 45.76 \\
\hline 1996 & $6,788,460$ & 9.6 & 78,539 & 32 & 45,249 & 15.82 & 33,290 & 63.02 \\
\hline 1997 & $7,446,220$ & 8.8 & 108,097 & 37.6 & 48,073 & 6.24 & 60,024 & 80.31 \\
\hline 2000 & $8,944,220$ & 8 & 159,590 & 14.5 & 59,840 & 14.8 & 99,750 & 14.4 \\
\hline 2001 & $9,731,480$ & 7.5 & 210,940 & 32.2 & 68,540 & 14.6 & 142,400 & 42.8 \\
\hline 2002 & $10,239,790$ & 8 & 305,415 & 44.6 & 77,981 & 13.3 & 227,464 & 59.7 \\
\hline 2003 & $11,652,850$ & 9 & 388,040 & 27.1 & 86,940 & 11.7 & 301,100 & 32.4 \\
\hline 2004 & $13,651,500$ & 9.5 & 431,810 & 11.3 & 108,990 & 25.1 & 322,820 & 7.2 \\
\hline 2005 & $18,232,100$ & 9.9 & 492,730 & 14 & 122,990 & 12.9 & 369,740 & 14.5 \\
\hline 2006 & $20,940,700$ & 10.7 & 564,140 & 14.4 & 150,940 & 22.6 & 413,200 & 11.8 \\
\hline 2007 & $24,661,900$ & 11.4 & 703,576 & 25 & 199,770 & 32.4 & 503,806 & 21.9 \\
\hline 2008 & $30,067,000$ & 9 & 978,410 & 39.6 & 233,671 & 16.97 & 744,739 & 47.82 \\
\hline 2009 & $33,535,300$ & 9.1 & $1,113,730$ & 13.8 & 287,580 & 23.1 & 826,150 & 10.93 \\
\hline 2010 & $40,120,200$ & 10.4 & $1,452,797$ & 30.4 & 389,564 & 35.46 & $1,063,233$ & 28.69 \\
\hline 2011 & $47,156,400$ & 9.2 & $1,433,925$ & 10.5 & 461,782 & 18.5 & 972,143 & 7.1 \\
\hline 2012 & $51,932,200$ & 7.8 & $1,550,000$ & 8 & 533,100 & 15.4 & $1,016,900$ & 4.6 \\
\hline
\end{tabular}

Secondly, personal insurance is still the leading portion, yet kept decreasing in recent years. China restored property insurance in 1980 and personal insurance in 1982, and the proportion of the latter rose from $0.16 \%$ to the dominating 55.53\% in 1997 and all the way to $77.6 \%$ in 2003. But since the global economic crisis, this number has gradually shrunk to $65.61 \%$ in 2012 , leaving the rest $34.39 \%$ to property insurance. The internal structure of the two has also shifted considerably. In property insurance, vehicle insurance occupies more than $75 \%$. In personal insurance, about $90 \%$ belong to life insurance and more than $90 \%$ are taken up by 
unconventional insurance, whose major part is the participating insurance. The detailed information is included in Table 2, 3, 4, 5, and 6 .

Thirdly, as the number of insurance company increases, the market is less concentrated, gradually forming a monopolistic competition. The total number of insurance company in China started from 1 in 1980 to 52 in 2001, 130 (Year Book of China's Insurance, 2012) in 2011 and 137 in 2012, among which 75 are life insurance companies and $62^{1}$ are property insurance companies. In the sense of market share, the proportion of the top three companies in life insurance dropped from $95.41 \%$ in 2001 to $66.6 \%$ in 2011 and $65.34 \%$ in 2012, while its counterpart in property insurance decreased from $95.25 \%$ in 2001 to $55.48 \%$ in 2011 and $55.15 \%$ in 2012 . If they expand the scope to the top five companies, in life insurance, their share shrank from $78.5 \%$ in 2008 to $71 \%$ in 2012 and, in property insurance, from $75.5 \%$ in 2008 to $74 \%$ in 2012 . This trend indicates a less concentrated market and a gradually formed monopolistic competition.

Table 2

Structure of Premium Income in China From 1980 to 2012

\begin{tabular}{|c|c|c|c|c|}
\hline Year & $\begin{array}{l}\text { Property insurance premium income } \\
\text { (million yuan) }\end{array}$ & $\begin{array}{l}\text { Proportion } \\
(\%)\end{array}$ & $\begin{array}{l}\text { Life insurance premium income } \\
\text { (million yuan) }\end{array}$ & $\begin{array}{l}\text { Proportion } \\
(\%)\end{array}$ \\
\hline 1982 & $1,028.4$ & 99.84 & 1.59 & 0.16 \\
\hline 1985 & 2,869 & 86.68 & 441 & 13.32 \\
\hline 1990 & 10,676 & 68.51 & 4,908 & 31.49 \\
\hline 1995 & 39,070 & 65.67 & 20,420 & 34.33 \\
\hline 1996 & 45,249 & 57.61 & 33,290 & 42.39 \\
\hline 1997 & 48,073 & 44.47 & 60,024 & 55.53 \\
\hline 2000 & 59,840 & 37.5 & 99,750 & 62.5 \\
\hline 2001 & 68,540 & 32.49 & 142,400 & 67.51 \\
\hline 2002 & 77,981 & 25.53 & 227,480 & 74.47 \\
\hline 2003 & 86,940 & 22.4 & 301,100 & 77.6 \\
\hline 2004 & 108,990 & 25.24 & 322,870 & 74.76 \\
\hline 2005 & 122,990 & 24.96 & 369,750 & 75.04 \\
\hline 2006 & 150,940 & 26.76 & 413,200 & 73.24 \\
\hline 2007 & 199,770 & 28.39 & 503,802 & 71.61 \\
\hline 2008 & 233,670 & 23.88 & 744,739 & 76.12 \\
\hline 2009 & 287,580 & 25.82 & 826,150 & 74.18 \\
\hline 2010 & 389,400 & 26.50 & $1,080,000$ & 73.50 \\
\hline 2011 & 461,782 & 32.20 & 972,143 & 67.80 \\
\hline 2012 & 533,100 & 34.39 & $1,016,900$ & 65.61 \\
\hline
\end{tabular}

Table 3

Insurance Business Structure in China From 2001 to 2012 in Percentage

\begin{tabular}{lrrrrrrrrrr}
\hline Business & 2001 & \multicolumn{1}{c}{2002} & \multicolumn{1}{c}{2003} & 2006 & 2007 & 2008 & 2009 & 2010 & 2011 & 2012 \\
\hline 1. Business Property Insurance & 17.69 & 15.74 & 14.37 & 11.01 & 9.35 & 8.97 & 7.7 & 6.74 & 7.15 & 6.76 \\
2. Family Property Insurance & 2.74 & 3.04 & 2.23 & 0.71 & 0.85 & 0.54 & 0.5 & 0.48 & 0.51 & 0.53 \\
\hline
\end{tabular}

\footnotetext{
1 The same standard is used as 2001 to calculate the numbers in 2011 and 2012, excluding insurance groups, insurance asset management company, and other companies.
} 
Table 3 to be continued

\begin{tabular}{lllllllllll}
\hline Business & 2001 & 2002 & 2003 & 2006 & 2007 & 2008 & 2009 & 2010 & 2011 & 2012 \\
\hline 3. Vehicle and Third-party & 61.33 & 60.6 & 62.13 & 73.4 & 74.3 & 72.86 & 74.96 & 74.6 & 75.95 & 75.16 \\
Liability Insurance & 0.91 & 0.98 & 1.42 & 1.56 & 1.58 & 1.68 & 1.72 & 1.76 & 1.6 & 1.17 \\
4. Project Insurance & 0.48 & 0.61 & 0.53 & 0.54 & 2.67 & 4.74 & 4.66 & 3.37 & 3.77 & 4.51 \\
5. Agriculture Insurance & 5.9 & 5.36 & 4.7 & 3.52 & 3.16 & 3.04 & 2.13 & 1.96 & 2.12 & 1.91 \\
6. Cargo Insurance & 4.02 & 4.73 & 4.01 & 3.56 & 3.33 & 3.5 & 3.21 & 2.88 & 3.21 & 3.45 \\
7. Liability Insurance & 0.43 & 0.95 & 0.96 & 1.81 & 1.74 & 1.57 & 2.44 & 2.38 & 2.5 & 3.01 \\
8. Credit Insurance & 0.61 & 1.18 & 0.23 & 0.53 & 0.21 & 0.27 & 0.27 & 0.57 & 1.22 & 1.75 \\
9. Bond Insurance & 5.89 & 6.79 & 9.42 & 1.9 & 2.79 & 2.83 & 2.41 & 5.26 & 1.98 & 1.73 \\
10. Others & & & & & & & & &
\end{tabular}

Table 4

Structure of Personal Insurance in China From 2000 to 2012

\begin{tabular}{lllllll}
\hline Year & $\begin{array}{l}\text { Life insurance } \\
\text { (million yuan) }\end{array}$ & $\begin{array}{l}\text { Proportion } \\
(\%)\end{array}$ & $\begin{array}{l}\text { Health insurance } \\
\text { (million yuan) }\end{array}$ & $\begin{array}{l}\text { Proportion } \\
(\%)\end{array}$ & $\begin{array}{l}\text { Accident insurance } \\
\text { (million yuan) }\end{array}$ & $\begin{array}{l}\text { Proportion } \\
(\%)\end{array}$ \\
\hline 2000 & 85,100 & 85.36 & 6,534 & 6.52 & 8,114 & 8.12 \\
2001 & 128,800 & 90.39 & 6,225 & 4.35 & 7,546 & 5.26 \\
2002 & 207,400 & 91.16 & 12,201 & 5.36 & 7,901 & 3.47 \\
2003 & 266,950 & 88.66 & 24,192 & 8.03 & 9,958 & 3.31 \\
2004 & 284,600 & 87.98 & 27,131 & 8.38 & 11,800 & 3.65 \\
2005 & 324,700 & 87.75 & 31,184 & 8.43 & 14,142 & 3.82 \\
2006 & 359,264 & 86.95 & 37,690 & 9.12 & 16,247 & 3.93 \\
2007 & 446,375 & 88.6 & 38,417 & 7.63 & 19,010 & 3.77 \\
2008 & 665,837 & 89.41 & 58,546 & 7.86 & 20,356 & 2.73 \\
2009 & 745,744 & 90.27 & 57,398 & 6.95 & 23,005 & 2.78 \\
2010 & 967,951 & 91.04 & 67,747 & 6.37 & 27,535 & 2.59 \\
2011 & 869,559 & 89.45 & 69,172 & 7.12 & 33,412 & 3.43 \\
2012 & 890,800 & 87.7 & 86,280 & 8.5 & 38,620 & 3.8 \\
\hline
\end{tabular}

Table 5

Development of Participating Insurance, Universal Insurance, and Investment-linked Insurance From 2002 to 2012 in Percentage

\begin{tabular}{llll}
\hline Year & Participating insurance & Universal insurance & Investment-linked insurance \\
\hline 2002 & 51.1 & 1.55 & 3.16 \\
2003 & 57.84 & 0.59 & 2.2 \\
2004 & 56.54 & 1.24 & 1.7 \\
2005 & 56.89 & 6.17 & 1.29 \\
2006 & 59.37 & 11.07 & 1.72 \\
2007 & 49.76 & 18.94 & 8.84 \\
2008 & 57.06 & 21.79 & 6.38 \\
2009 & 70.97 & 14.15 & 1.98 \\
2010 & 77.02 & 11.61 & 1.58 \\
2011 & 77.99 & 11.45 & 1.18 \\
2012 & 75.57 & 14.65 & 0.68 \\
\hline
\end{tabular}


Table 6

Structure of Life Insurance Product From 2002 to 2012

\begin{tabular}{lll}
\hline Year & $\begin{array}{l}\text { Conventional Life Insurance } \\
(\%)\end{array}$ & $\begin{array}{l}\text { Life insurance premium income } \\
(\%)\end{array}$ \\
\hline 2002 & 44.19 & 55.81 \\
2003 & 39.37 & 60.63 \\
2004 & 40.52 & 59.48 \\
2005 & 35.65 & 64.35 \\
2006 & 27.84 & 72.16 \\
2007 & 22.46 & 77.54 \\
2008 & 14.77 & 85.28 \\
2009 & 12.9 & 87.1 \\
2010 & 9.79 & 90.21 \\
2011 & 9.38 & 90.62 \\
2012 & 9.1 & 90.9 \\
\hline
\end{tabular}

Fourthly, the investment channel of insurance is being perfected and investment plays a more significant role in promoting the development of the industry, however with a relatively low rate of return. Since the Insurance Law was issued in 1995, the channel is constantly being perfected. The range was at first set to bank deposit, financial bond, government bond, and other forms approved by the State Council in 1995 and was then revised in 2009 into a broader one as bank deposit, security, real estate, and other forms approved by the State Council. In 2012, the China Insurance Regulatory Commission (CIRC) adopted a series of new policies that allow investing in financial derivative, which is favorable for managing investment risk, raising rate of gain, and promoting product innovation. But due to the global economic crisis since 2008, the rate of return of insurance in China has remained at a comparatively low level, bringing pressure on the profiting and underwriting capacity of insurance companies. Even though the rate of return reached as high as $12.2 \%$ in 2007, the annual average over the 11 years from 2001 to 2011 was merely $4.7 \%$, barely higher than the interest rate of a 5-year bank deposit. In 2012, this rate fell to 3.38\%. The depression in capital market is the main cause in such low rate of return, the detailed information of which is the provided in Table 1 and Figure 1.

Table 7

Comparison between Rate of Return of Insurance Investment and Bank Interest From 2001 to 2011 in Percentage

\begin{tabular}{lllllllllllll}
\hline & 2001 & 2002 & 2003 & 2004 & 2005 & 2006 & 2007 & 2008 & 2009 & 2010 & 2011 & Average \\
\hline Rate of Return of & 4.3 & 3.1 & 2.7 & 2.9 & 3.6 & 5.5 & 12.2 & 1.9 & 6.4 & 4.9 & 3.6 & 4.7 \\
Insurance Investment & 2.9 & 2.8 & 2.8 & 3.0 & 3.6 & 3.8 & 5.1 & 5.4 & 3.6 & 3.8 & 5.3 & 3.8 \\
Bank Interest $^{\mathrm{a}}$ & 2.9 & &
\end{tabular}

Note. ${ }^{\text {a }}$ Interest rate of 5-year deposit, averaged by 12 months.

Fifthly, supervision on insurance industry is improved, as well as its public image. China has established a system of laws and regulations centered on the Insurance Law to provide legal support for an ordered development. As for the supervision philosophy, it has been focused on protecting consumer's interest in recent years and achievements have been made in eliminating misleading in sales and facilitating claim settlement. Also, improvements are made in the information disclosure mechanism in the industry. The supervision system, which is concentrated on solvency, contributes to future development of the industry. 


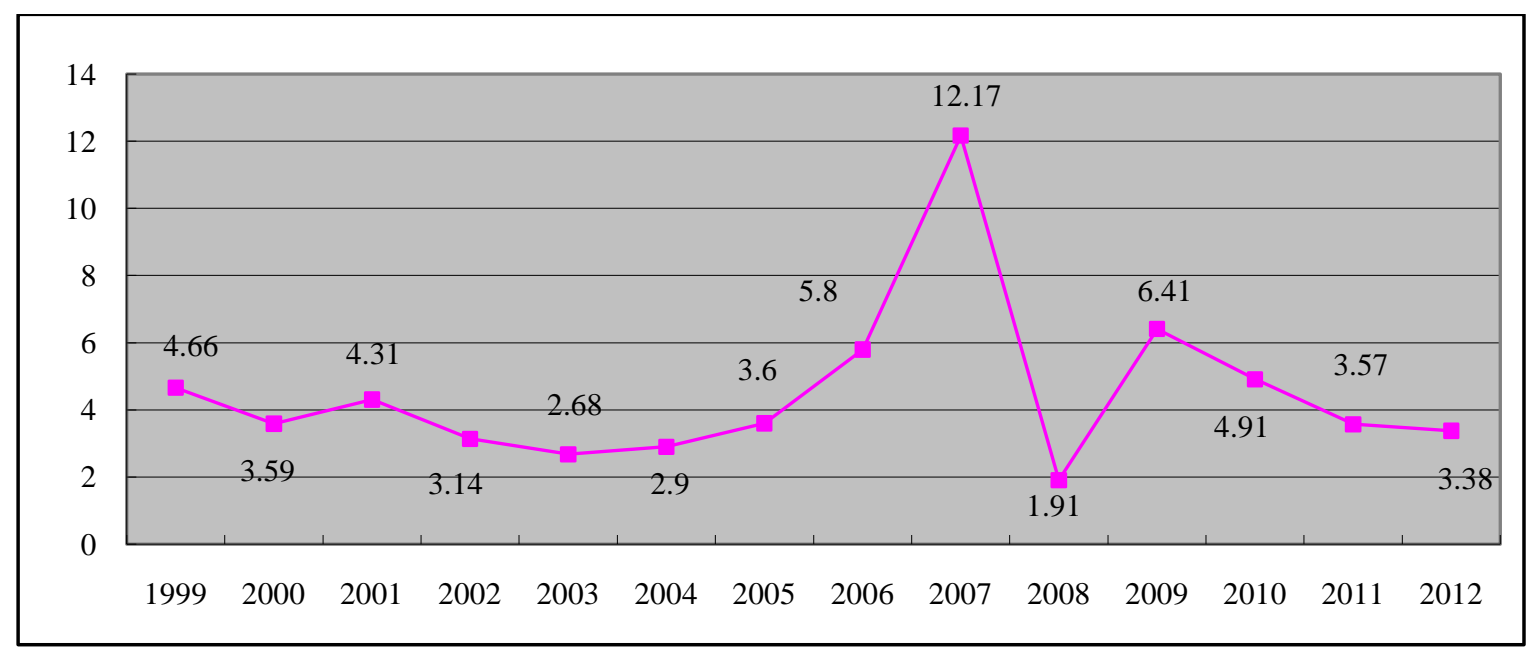

Figure 1. Rate of return of insurance investment from 1999 to 2012.

\section{Existing Contradictions in Chinese Insurance Industry}

Chinese insurance industry is currently faced with several contradictions that are mostly reflected under the pressure of both slowed growth of premium income and decreased investment return. On one hand, the annual growths in premium income from 2009 to 2011 are respectively 13.8\%, 30.4\%, and 10.5\%, but 2012 witnessed the first single-digit growth rate in 20 years of merely $8 \%$. On the other hand, the rate of return on investment in the capital market has been on a downturn, from $6.41 \%$ in 2009 to $4.94 \%$ in $2010,3.57 \%$ in 2011 and $3.38 \%$ in 2012.

Firstly, the current market economy system does not fully satisfy the demand of commercial insurance. Commercial insurance is one of the indispensable constituents of market economy and, in turn, market economy is its prerequisite. Also, commercial insurance requires a sound civil law system and a market-oriented independent operation. However, these conditions are not yet met in the status quo.

Secondly, social security system is not well coordinated with commercial life insurance. The coverage of the social security system is mainly limited to the labor force in urban population, leaving massive rural population and part of urban population not covered (Wang, 2011). As for the covered group, usually the liability standard is rather high. In a sense, the excessive coverage on a limited group has effectively occupied the position of commercial life insurance, impairing its complementary role. Furthermore, the uncovered has the basic need for social security but is often unable to afford extra coverage, while the covered enjoys so much more than basic coverage from social security that lacks the need for commercial insurance as a complement but rather as an investment (Wang, 2009). This results in the unreasonably high proportion of investment type products in life insurance market, which also has to do with insufficient investment channels for the public.

Thirdly, the instability in capital market is disadvantageous to the development of insurance market. The capital market and insurance market are tightly related. For one thing, insurance market is a major factor of a sound capital market. According to foreign experience, insurance investment is a principal capital source, an institutional, long-term and value investor, contributing to the stability of capital market. In turn, the capital market is a major source of profit for the insurance investment. Therefore, product innovation has a crucial role to the development of the insurance industry. As competition in the market intensifies, it is common for modern insurance industry to operate under deficit in underwriting, but to profit from investment and achieve overall 
gain eventually. However, the profitability of insurance investment suffers from the instability of capital market in China, which barricades the product innovation and further the development of insurance industry. The annual average rate of return on investment of Chinese insurance industry over the 11 years spanning from 2001 to 2011 is only $4.7 \%$ and even worse for the last two years. The depression in capital market has severely degraded the rate of return on investment of the insurance industry as illustrated in Table 8 and Table 9. This has affected the competitiveness of not only life insurance product that features the function of saving or investment but also non-life insurance product, which, in developed countries, usually achieves overall gain using profit from investment to make up for the deficit in underwriting (Table 10). However, due to the extremely low rate of return on investment, Chinese insurance industry has to seek profit in underwriting, which impairs consumer's willingness to purchase and potential business expansion of property insurance.

Fourthly, the underdeveloped company management is inconsistent with the fast growing business. Since 1980, Chinese insurance industry has been developing rapidly, with an annual premium growth rate close to $30 \%$ and a constantly increasing investment profit. But company management failed to keep up the same pace, especially the problem of the ownership. It leads to the difficulty in the establishment of a board of directors or a board of supervisors that answer to the shareholders. As a result, a proper incentive mechanism is yet to be put in place.

Table 8

Investment Allocation of Insurance Companies in 2011

\begin{tabular}{lcccc}
\hline & $\begin{array}{l}\text { Investment amount } \\
\text { (million yuan) }\end{array}$ & $\begin{array}{l}\text { Proportion } \\
(\%)\end{array}$ & $\begin{array}{l}\text { Return } \\
\text { (million yuan) }\end{array}$ & $\begin{array}{l}\text { Rate of return } \\
(\%)\end{array}$ \\
\hline 1. Bank deposits & $1,773,717$ & 31.97 & 66,128 & 4.14 \\
2. Bonds & $2,612,469$ & 47.09 & 105,696 & 4.38 \\
(1). Treasury bonds & 474,240 & 8.55 & 20,530 & 4.24 \\
(2). Financial bonds & $1,248,520$ & 22.51 & 48,224 & 4.42 \\
(3). Corporate bonds & 882,503 & 15.91 & 36,617 & 4.4 \\
3. Securities investment funds & 291,585 & 5.26 & $-4,420$ & -1.49 \\
4. Buy-backs of assets & 25,146 & 0.45 & 1,573 & 4.31 \\
5. Stocks & 380,187 & 6.85 & $-10,331$ & -2.61 \\
6. Long-term stock investments & 195,323 & 3.52 & 9,151 & 5.09 \\
7. Real estates & 31,012 & 0.56 & 4,231 & 18.2 \\
8. Insurance asset management products & 7,229 & 0.13 & 150 & 1.95 \\
9. Financial derivative instruments & 290 & 0.01 & 9 & 10.51 \\
10. Loans & 200,311 & 3.61 & 7,199 & 5.28 \\
11. Borrowing & 84 & 0 & 0 & 0 \\
12. Others & 30,031 & 0.54 & 3,214 & 14.35 \\
Total & $5,547,385$ & 100 & 182,600 & 3.57 \\
\hline
\end{tabular}

Fifthly, self-discipline of the industry needs to be strengthened. The self-discipline has fallen behind the fast development of the insurance industry. Corresponding organizations need to play a more significant role in defending the interest of the entire industry. The key is to set up the appropriate organizational structure and regulatory framework around the interest of the industry, letting various self-discipline organizations to speak for themselves. 
Table 9

Investment Allocation of Insurance Company in 2012

\begin{tabular}{lcccc}
\hline & $\begin{array}{l}\text { Investment amount } \\
\text { (million yuan) }\end{array}$ & $\begin{array}{l}\text { Proportion } \\
(\%)\end{array}$ & $\begin{array}{l}\text { Return } \\
\text { (million yuan) }\end{array}$ & $\begin{array}{l}\text { Rate of return } \\
(\%)\end{array}$ \\
\hline 1. Bank deposits & $2,034,309$ & 33.59 & 94,311 & 4.64 \\
2. Bonds & $2,748,125$ & 45.37 & 128,815 & 4.69 \\
(1). Treasury bonds & 473,121 & 7.81 & 20,184 & 4.27 \\
(2). Financial bonds & $1,306,735$ & 21.58 & 61,428 & 4.70 \\
(3). Corporate bonds & 959,810 & 15.85 & 47,031 & 4.90 \\
3. Securities investment funds & 294,209 & 4.86 & $-25,428$ & -8.64 \\
4. Buy-backs of assets & 47,356 & 0.78 & 1,462 & 3.09 \\
5. Stocks & 388,796 & 6.42 & $-30,639$ & -7.88 \\
6. Long-term stock investments & 190,532 & 3.15 & 14,243 & 7.48 \\
7. Real estates & 34,277 & 0.57 & 2,916 & 8.51 \\
8. Insurance asset management products & 23,600 & 0.39 & 775 & 3.28 \\
9. Financial derivative instruments & 222 & 0.00 & -26 & -11.90 \\
10. Loans & 256,986 & 4.24 & 14,064 & 5.47 \\
11. Borrowing & 84 & 0.00 & -1 & -0.97 \\
12. Others & 38,140 & 0.63 & 3,919 & 10.28 \\
Total & $6,056,639$ & 100.00 & 204,412 & 3.38 \\
\hline
\end{tabular}

Table 10

Rate of Return for Non-life-insurance Companies in Different Countries (\%)

\begin{tabular}{|c|c|c|c|c|c|c|}
\hline & $\begin{array}{l}\text { United States } \\
94-04\end{array}$ & $\begin{array}{l}\text { Canada } \\
94-04\end{array}$ & $\begin{array}{l}\text { United Kingdom } \\
94-04\end{array}$ & $\begin{array}{l}\text { Germany } \\
94-04\end{array}$ & $\begin{array}{l}\text { France } \\
95-04\end{array}$ & $\begin{array}{l}\text { Japan } \\
96-04 \\
\end{array}$ \\
\hline Claim Ratio & 78.7 & 73.3 & 73 & 71.3 & 80.8 & 61.2 \\
\hline Expense Ratio & 26.4 & 29.8 & 31.2 & 27.5 & 23.3 & 38.1 \\
\hline Dividend Ratio & 1.1 & n.m & n.m & 1 & 1.1 & 0.1 \\
\hline Combined Ratio & 106.2 & 103.1 & 104.2 & 99.9 & 105.2 & 99.4 \\
\hline $\begin{array}{l}\text { Standardized } \\
\text { Underwriting } \\
\text { Performance }\end{array}$ & -6.9 & -3.7 & -4.7 & -2.4 & -6.1 & 0.4 \\
\hline $\begin{array}{l}\text { Net Investment } \\
\text { Performance }\end{array}$ & 16.2 & 13.8 & 16.8 & 15.4 & 13.4 & 4.7 \\
\hline $\begin{array}{l}\text { Other } \\
\text { Expenses/Revenues }\end{array}$ & 0 & 0.4 & -0.5 & -0.3 & -0.3 & -0.8 \\
\hline Rate of Return (pretax) & 9.2 & 10.4 & 12.8 & 12.7 & 7 & 4.4 \\
\hline
\end{tabular}

Sixthly, the internationalization of insurance market is restricted by the administrative system. It has been 12 years since China joined the WTO and the insurance market is fairly open to the world. Product and price are important marketing strategy, however, in China, approvals from the authority on both premium rate and specific clause in the policy are needed for those life insurance products that are newly developed or that concern the public interest. Particularly, the interest rate of life insurance is required to be no more than $2.5 \%$ and discount on vehicle insurance could not be more than $30 \%$, which, to some extent, retrain the public demands and future development.

Seventhly, expansion of business is conflicting with enhancement of efficiency. Insurance companies are actually raising commission to compete for a larger market share. On the other hand, they have to emphasize 
efficiency, especially for some property insurance companies, who managed to lower the total cost ratio to less than 100\%. In such cases, claim ratio reduced, but expense ratio was, in fact, increased in 2009 and 2010. Assuming that the compensation standards remain the same, this increase in efficiency is actually achieved at the price of a poorer management and lower coverage standard for the insured. Of course, according to Table 11, a decreased cost ratio and an increased claim ratio in 2011 and 2012 indicate improvement in management and consumer's benefit.

Table 11

Total Cost Ratio and Claim Ratio From 2006 to 2012 (\%)

\begin{tabular}{lccccccc}
\hline & 2006 & 2007 & 2008 & 2009 & 2010 & 2011 & 2012 \\
\hline Total cost rate & 102.7 & 114.2 & 106.7 & 104.5 & 97.3 & 95.26 & 97.23 \\
Claim ratio & 52.75 & 51.81 & 60.7 & 54.79 & 45.08 & 61.22 & 61.25 \\
Total expense ratio & 49.95 & 62.39 & 46.0 & 49.71 & 52.22 & 34.54 & 35.98 \\
\hline
\end{tabular}

Eighthly, the market potential is not fully exploited, but unbalanced structure hinders its release. The insurance rate in China is relatively low. In 2012, for example, $87.7 \%$ of the personal insurance businesses are life insurance, the rests are health insurance of $8.5 \%$ and accident insurance of merely $3.8 \%$, while within life insurance, conventional business takes up only $9.8 \%$, a relatively low proportion of risk management product; as for property insurance, vehicle insurance occupies $75.16 \%$. Other types of insurance need to be further exploited.

Ninthly, the public welfare nature of the compulsory traffic accident liability insurance for motor vehicles contradicts its marketization. The corresponding regulation puts emphasis on the non-profit principle while, at the same time, demands direct operation, which are seriously mismatched with each other. Only under agent mode can non-profit-non-deficit operation be achieved, otherwise, under direct mode, non-profit-non-deficit operation cannot be achieved on both company scale and industry scale according to the law of large numbers. But it is the nature of an insurance company to maximize its profit. Binding public welfare with marketization will lead to ambiguous boundary between market and government, diminishing the enthusiasm of insurance company.

Tenthly, the development of China's insurance industry has a clear regional difference. The unbalanced development in economy results in that in insurance industry, too. Developed regions, as represented by Guangdong, Jiangsu, Beijing, Shanghai, Zhejiang, and Shandong, have sufficient suppliers and massive demands, bringing high premium income. The central and western region, however, not only is less developed but also has a poor awareness of insurance, contributing less to the total premium income. Details are provided in Table $12 .^{2}$

It can be seen from Table 12 that the premium incomes of the 16 provinces and cities in the eastern region add up to 895.506 billion yuan, equivalent to $57.82 \%$ of the total in the country, with that being 352.623 billion yuan and $22.77 \%$ of the total for the eight provinces and cities in the central region. The western region accounts for 292.235 billion yuan, $18.87 \%$ of the total premium income. The top five premium income comes from Guangdong province, Jiangsu province, Shandong province, Beijing, and Shanghai, all belonging to the eastern region and amounting to a number much larger than the central or western region of 503.686 billion

\footnotetext{
${ }^{2}$ Business from groups and headquarters, amounting to $8,428.6023$ million yuan, is not attributed to any regions, however, the majority should belongs to Eastern China.
} 
yuan. In areas where the insurance industry is less developed, the total share of the five provinces, Guizhou, Hainan, Qinghai, Ningxia, and Tibet, is only $2.03 \%$, less than that of a middle-level province. Imbalance is a grave problem in the development of insurance industry.

Table 12

Premium Income in Different Regions of China in 2012

\begin{tabular}{|c|c|c|c|c|c|}
\hline Region & $\begin{array}{l}\text { Premium income } \\
\text { (million Yuan) }\end{array}$ & Proportion (\%) & Region & $\begin{array}{l}\text { Premium income } \\
\text { (million Yuan) }\end{array}$ & Proportion (\%) \\
\hline Eastern China & $895,506.3217$ & 57.82 & Heilongjiang & $34,414.9837$ & 2.22 \\
\hline Beijing & $92,308.7131$ & 5.96 & Anhui & $45,361.2517$ & 2.93 \\
\hline Tianjin & $23,815.715$ & 1.54 & Jiangxi & $27,171.8884$ & 1.75 \\
\hline Hebei & $76,615.8299$ & 4.95 & Henan & $84,113.1801$ & 5.43 \\
\hline Liaoning & $40,241.5779$ & 2.60 & Hubei & $53,331.0559$ & 3.44 \\
\hline Dalian & $16,061.9948$ & 1.04 & Hunan & $46,511.4274$ & 3.00 \\
\hline Shanghai & $82,063.6807$ & 5.30 & Western China & $292,235.29$ & 18.87 \\
\hline Jiangsu & $130,128.048$ & 8.40 & Chongqing & $3,310,267.03$ & 2.14 \\
\hline Zhejiang & $81,987.6977$ & 5.29 & Sichuan & $8,195,283.43$ & 5.29 \\
\hline Ningbo & $16,470.5624$ & 1.06 & Guizhou & $1,502,155.49$ & 0.97 \\
\hline Fujian & $38,477.8842$ & 2.48 & Yunnan & $2,712,984.03$ & 1.75 \\
\hline Xiamen & $9,291.7667$ & 0.60 & Tibet & $95,372.34$ & 0.06 \\
\hline Shandong & $96,774.7993$ & 6.25 & Shaanxi & $3,653,273.14$ & 2.36 \\
\hline Qingdao & $16,028.8055$ & 1.03 & Gansu & $15,876.7491$ & 1.03 \\
\hline Guangdong & $129,085.6191$ & 8.33 & Qinghai & $3,240.0753$ & 0.21 \\
\hline Shenzhen & $40,126.5705$ & 2.59 & Ningxia & $6,268.8277$ & 0.40 \\
\hline Hainan & $6,027.0569$ & 0.39 & Xinjiang & $23,556.0368$ & 1.52 \\
\hline Central China & $352,622.77$ & 22.77 & Inner Mongolia & $24,774.372$ & 1.60 \\
\hline Shanxi & $38,464.9109$ & 2.48 & Guangxi & $23,825.8713$ & 1.54 \\
\hline Jilin & $23,254.0721$ & 1.50 & Total & $1,548,792.98$ & 100 \\
\hline
\end{tabular}

Source: Year Book of China's Insurance (2013).

\section{Analysis on the Environment of Insurance Industry}

The environment can be divided into domestic and international environment. Globalization, financial liberalization, and global economy fluctuation remain to be the themes of the international environment. The globalization of economy includes the penetration and expansion of foreign capital, accelerating the acquisition and reorganization within the industry, and also directly bringing new competition. The financial liberalization is favorable to the economies of scale and product innovation, but, at the same time, is accompanied with enormous potential risk and the possibility of the absence of supervision. The global economy fluctuation brings about instability, such as the western debt crisis and decrease in demands.

The domestic environment can be further divided into economic and social environment. The former includes the fluctuation and restructuring in the growing national economy, strategic adjustment in regional economy structure, the trend of financial integration, improvements in investment environment, imbalance of development between regions and between urban and rural area, and the relatively large regional difference in risks. The latter mainly consists of the population aging, the development of the social security system, the enhancement of the legal system, and people's rising awareness of insurance and rule of law (Wang, 2007). 
These domestic influences are collectively embodied in a series of policies: the ones on economy development that aim at maintaining the growth and adjusting the structure, including a moderately loose monetary policy and a proactive fiscal policy; the ones on urbanization; the ones on allocation led by doubling the income and creating income with purchasing power of 64 trillion yuan; the ones on the liberalization of interest rate; and the ones on fully implementing the social security system. These policies will motivate the recovery of capital market, bringing increase in demands and structural change in the insurance industry.

\section{Conclusions}

Based on the current macroeconomic trend and development in capital market, possible solutions are as follow:

Firstly, it further pushes the marketization of the economy. Fundamental features of market economy are private property, freedom of contract, self-responsibility. These are the basis of market economy and also the premise of strengthening company management. Only when the ownership is clarified, can the investors have enough incentive and companies face the demands of the market and gain profit. Also, since commercial insurance is an indispensable element of the market economy and, in turn, its premise, insurance company should invite more private sector into its shares (Wang \& Xi, 2010). This will vitalize the market and lead to better performance of insurance.

Secondly, it raises the general awareness of insurance. This includes the awareness of the consumer, the government, and the insurer. As for the government, it is to understand the function of insurance as a social stabilizer and economic propeller (Wang, 2013a). Measures, such as tax exemption, tax extension, pretax deductible and financial subsidies, can be done by the government to encourage purchase of insurance and further to resolve social risks. Meanwhile, the development of insurance industry will contribute to the stability of capital market and economic growth. Insurer also needs to fully understand the function of insurance, especially the ones of hazard and loss prevention, and disbursement of compensation and payment. Insurance company should work on these risk managing functions and, by reasonable and effective underwriting and timely and equitable claim settlement, bring the benefits to the people, and thus the desire for insurance.

Thirdly, it promotes market-oriented policy premiums. Under market economy, product strategy and price strategy are crucial to marketing. After 33 years since China restored its insurance industry, insurance companies are now equipped with the ability to draft clauses and set policy premium. Besides, it has been 12 years since China joined the WTO. It is practical and necessary to push forward the marketization reform on policy clause and premium in order to motivate the development of the industry.

Fourthly, it appreciates the importance of statistics in insurance. On premium rate, China has compiled the mortality table several times as a numerical basis to help scientifically determine the appropriate premium. But beyond life insurance, similar research has to be strengthened, especially for motor vehicle insurance. A motor vehicle collision research center should be established under the lead of the Insurance Association of China, with insurance companies as members. The research results can serve as a basis for premium rate and the social influence of the insurance industry will also be enhanced.

Fifthly, it diversifies sales channel. At the moment, the sales channels in insurance industry are direct selling, agency, and broker mode. As the marketization of bank interest proceeds, the weight of bancassurance will increase. Also, the proportion of sales over the internet and telephone will take on an upward trend with the course of urbanization. In a word, new vitality will be brought to the industry. 
Sixthly, it optimizes the industrial structure. It includes the structure of product and service and also the balance of regional distribution (Wang, 2013b).

The structure optimization of product should include improvement on risk managing product, exploration on investment type product, and development of derivative product. For the traditional risk managing product, such as motor vehicle insurance, business property insurance, family property insurance, cargo insurance, project insurance, the improvement should be innovation on products that horizontally satisfies the cross-field demands and vertically inspires the potential market. As for the unconventional product, the main task is to design the strategy accordingly to expand the business, for example, insurance company should focus on the policy-favored products for agricultural business, seek governmental support in laws and policies for liability insurance products, and coordinate the business mode and operation principle in compulsory motor vehicle insurance. For the investment type product, it is important to maintain its correspondence to the risk in capital market. As regards the derivative product, insurance companies need to keep an eye out for the latest development in the world and put emphasis on thorough researches to effectively offset grave disasters and losses.

Balancing regional distribution lies in differentiation that operation mode should serve local economy, organizational structure should meet the needs in different districts on various levels, service, and product should be tailored to the diverse demands over a broad demographical range of consumers, and sales channels should accommodate local conditions, especially to open up to agency mode and cross-selling, ${ }^{3}$ to reduce cost. Differentiation will not only reduce costs, but also manage risks. In achieving reasonable regional distribution, certain favorable policies contribute to the process, such as tax benefit, market access, investment preference.

Seventhly, it fosters specialized personnel. Talent is the first productive force, in which lies the future of the industry. In order to promote sustainable development and competitiveness of the industry, what is urgent now is to set assessing standards and establish training system.

Eighthly, it routinizes self-discipline measures. Since the Insurance Association of China represents the interest of the industry, its organizational structure and regulatory regime have an essential role in coordinating the development of the industry, maintaining fair competition in the market, and promoting the social influence of the insurance industry.

Ninthly, it improves the flexibility in investment. Insurance investment is the foundation of future development and innovation of the industry. Based on the enhancement of domestic capital market and insurance company's investing capacity, further improvement could made in two aspects: supervision and operation. On the former, restrictions on investing methods should be further unleashed while making adjustments on the investment structure. As for operation, insurance company needs to refine its decision-making process and expertise in investment. When selecting the investment project, insurance company should favor those with high and fast return to avoid credit risk, and stick to the procedure to maintain security, flexibility, and profitability in investment. As a result of enhanced profitability, insurance company will acquire higher solvency and competitiveness.

Tenthly, it systematically integrates the social security system and the commercial insurance. The goal is to realize a united social security system across urban and rural area and to fully exploit the complementary function of commercial life insurance. The social security system and commercial insurance have their

\footnotetext{
${ }^{3}$ It should be pointed out that currently there are companies that have adopted cross-selling or have expanded business beyond assigned territory, which is a worthy attempt of system innovation.
} 
competing aspect as well as mutual encouragement. A well-coordinated integration of the two constitutes the protection system of the national economy (Wang, 2013c). It contains a thorough social security system that promotes equal public service in both urban and rural districts, and a commercial insurance industry that utilizes its commerciality and expertise to satisfy the further demands in the market.

In conclusion, an economically strong nation must have a developed insurance industry as its backup. Insurance acts as a stabilizer for social development and a booster for economic growth. A developed insurance industry is a key factor of a stable capital market, yet a vigorous capital market is advantageous for further advance of the insurance industry. A systematic resolution of the low-growth and low-return issue in the insurance market is favorable to both the long-term social and economic development.

\section{References}

Daniel Staib. (2011). Sigma: World insurance in 2010. Luzern: Swiss Re Ltd economic research and consulting.

Ulrike Birkmaier. (2002). Sigma: World insurance in 2002. Luzern: Swiss Re Ltd economic research and consulting.

Wang, X. (2007). On the choice of China's insurance market mode. Insurance Studies, 7, 67-68.

Wang, X. (2009). A study on China's property insurance market. Insurance Studies, 1, 36-37.

Wang, X. (2011). Insurance. Beijing: Higher Education Press.

Wang, X. (2013a). The citizens' awareness is the footing stone of the development of insurance industry. Insurance Culture, 9, 24-25.

Wang, X. (2013b). Slow growth and low profit rate in insurance industry. Finance World, 8, 70-71.

Wang, X. (2013c). Insurance boosts urbanization in China. Finance World, 5, 58-59.

Wang, X., \& Xi, Y. (2010). China's insurance market during economic recovery period. China Commercial Insurance, 2, 41-42.

Year Book of China's Insurance. (2012). A summary of China's personal insurance market in 2011. Beijing: China Insurance Regulatory Commission.

Year Book of China's Insurance. (2013). Investment allocation of insurance company in 2012. Beijing: China Insurance Regulatory Commission. 